\title{
Building Collective Identities: How New Social Movements Try to Overcome Post-politics
}

\author{
Thomas Decreus, Matthias Lievens and Antoon Braeckman
}

This is the manuscript of a paper which appeared in a special issue of the journal Parallax on 'Chantal Mouffe: agonism and the politics of passion', Volume 20, Issue 2, 2014, pp. 136148.

Check the following website for the published version:

http://www.tandfonline.com/doi/full/10.1080/13534645.2014.896560\#.U2Oi3oGSySo

Recent protest movements such as the Indignados and Occupy advocate what they call 'real democracy'. They radically reject representative democracy as implemented within existing institutions, and the distinction between rulers and ruled which results from it. The movements themselves appear to be leaderless and without clear structure. Unsurprisingly, anarchist, autonomist or post-operaist interpretations of these movements have been paramount. ${ }^{1}$ Indeed, it is tempting to interpret these 'leaderless' movements in terms of multitudes spontaneously organising themselves, or to understand Occupy and the Indignados' fierce rejection to engage with institutionalised politics as a form of 'exodus'.

In her recent work, Chantal Mouffe formulates a strong critique of prevailing post-operaist interpretations of the recent protest movements. In the last instance, her opposition to postoperaism is grounded in a post-foundational ontology which radically differs from the immanentist ontology underpinning post-operaism. According to Mouffe, the latter does not acknowledge the dimension of radical negativity which manifests itself in the ever-present possibility of antagonism. ${ }^{2}$ As a result, the post-operaist understanding of 'real' democracy, the multitude and exodus become highly problematic, as it tends to underestimate the exclusions involved in the very constitution of collective agencies.

Surprisingly, however, Mouffe does not engage in a post-foundationalist (re-)interpretation of movements like Occupy and the Indignados. She limits herself to rejecting the post-operaist description and then goes on to criticise these movements from a mainly strategic perspective. According to Mouffe, the Occupy and similar movements are strategically ineffective since they are not able to develop a counter-hegemonic political project that truly challenges the existing order. What is needed, she claims, is a genuine political force which does not limit itself to extra-parliamentary struggle, but combines both extra-parliamentary and parliamentary struggle. In this context she refers to Syriza in Greece and the Front de Gauche in France as examples.

Although we generally sympathise and agree with Mouffe's critical remarks, in this paper we want to follow a slightly different route. Instead of focusing on a strategic and ontological critique, we think it might be useful to use Mouffe and Laclau's post-foundational theory of hegemony as a descriptive tool in order to re-interpret the recent protest movements. Rather than juxtaposing new and more traditional protest movements on the basis of strategic concerns or the ontology of their predominant theorisations, we must try to understand why the present constellation tends to generate the new type of movements that we recently 
witnessed. As we will argue, the current constellation, for a number of reasons, makes the construction of a 'we', a collective identity that can stimulate the passions of the many, particularly challenging. Therefore, it is no coincidence that recent protest movements have paid special attention to symbols and to how these may contribute to carve out new spaces for the emergence of political identities. This symbolic and even theatrical dimensions of recent protest movements deserve our utmost attention, not only since they are politically salient, but because they embody basic tenets of Mouffe's own agonistic or discourse-theoretical approach, in which the construction of a 'we' and the role of representations take centre stage.

\section{Constructing a 'We'}

In the conclusion of her latest book, Agonistics, Mouffe claims she wants to "examine the responses of radical political theorists to these movements [i.e. the recent mobilizations in liberal democratic societies] and the different ways in which these movements have been interpreted'. ${ }^{3}$ Yet, according to us, besides the interpretations examined and criticized by Mouffe, there is one important interpretation missing, namely a re-interpretation of the recent protest movements from the point of view of Mouffe's and Laclau's theory of hegemony. The fact that the movements' activists often interpret their own activity in post-operaist rather than in counter-hegemonic or agonistic terms, does not preclude such a re-interpretation. In actual fact, looking at the recent movements from this alternative perspective may lead to a better understanding of their possible shortcomings.

Let us briefly recall the core elements of Mouffe's post-foundational theory of hegemony. Mouffe understands the concept of hegemony first and foremost as an articulatory practice whereby floating signifiers are fixed within a network of signifying chains. These signifying chains are always constructed vis-à-vis an excluded element that serves as a constitutive outside. ${ }^{4}$ Essentially, hegemony points to a constitutive logic: it is an attempt to suture a dislocated space and to create a new space of representation in which a variety of demands can be inscribed. ${ }^{5}$ However, hegemonisation is always characterized by contingency. Any articulatory practice requires the repression of alternative possibilities and the reason for excluding one alternative over the other is based on a decision which has only itself as a

(non-) ground. The terrain of structural undecidability thus functions as condition of possibility and final impossibility of any attempt to hegemonise the field of discursivity. ${ }^{6}$

Important from our perspective is the fact that hegemony is essentially an attempt to rearticulate dislocated elements into 'new spaces of representation that attempt to suture the dislocated space in question'. ${ }^{7}$ In this regard, the Occupy movement and its continental twin sister, the Indignados, can be considered as responses to growing dislocations caused by the financial crisis and the ensuing debt crisis. People lost their jobs, unemployment rose, politics seemed powerless and growing discontent found no ways to express itself. However, the Occupy movement, through the practice of occupying city squares, created a space of representation for a wide variety of demands that had no strict logical connection to one another. In this sense, the assemblies cannot be considered merely decision-making tools. The assemblies enabled the movement to represent itself to itself and to understand itself as one. ${ }^{8}$ Demands for reforms of the tax system, carbon reduction, revolutionary action and a fair redistribution of wealth became all represented in the same symbolic space. Occupy made these demands visible and representable by re-articulating them in a chain of equivalence 
structured around nodal points like 'real democracy', 'Occupy' and 'the 99\%'. These nodal points functioned as empty signifiers under which the chain of equivalence was remarkably broadened. In the discourse of the Spanish Indignados, for example, this chain stretched from 'progressives' to 'conservatives'. The opening lines of their Manifesto read as follows:

We are ordinary people. We are like you: people, who get up every morning to study, work or find a job, people who have family and friends. People, who work hard every day to provide a better future for those around us. Some of us consider ourselves progressive, others conservative. Some of us believers, some not. Some of us have clearly defined ideologies, others are apolitical, but we are all concerned and angry about the political, economic, and social outlook which we see around us: corruption among politicians, businessmen, bankers, leaving us helpless, without a voice. This situation has become normal, a daily suffering, without hope. But if we join forces, we can change it. It's time to change things, time to build a better society together. ${ }^{9}$

It is tempting to read the opening lines of this manifesto as the ultimate example of a postpolitical logic. At first glance, political and ideological cleavages are denied. The only possible identification is one with a nameless and unproblematic 'we, the people'. This seemingly post-ideological 'we, the people' is simply called upon to 'join forces' in order 'to build a better society together'. Strikingly, these lines could perfectly have been the opening paragraph of a neoliberal, socialist, fascist or anarchist manifesto.

However, these opening lines may also be read in an alternative way. Indeed, the seemingly post-political call for mobilisation can also be interpreted as an attempt to create a chain of equivalence that is as wide as possible. This might also be the reason why both the Occupy and the Indignados refused to identify themselves with a formal program containing concrete demands. As Laclau has argued, the vaguer the political demands, the more differing demands it can incorporate, and the more people who may identify with the nascent counter-hegemonic discourse. Hence vagueness is constitutive for social unity. ${ }^{10}$ The consequence is that the differences between the links in the equivalential chain tend to be neutralized: conservative and progressive, believers and non-believers are considered to be part of the same 'people'. ${ }^{11}$

However, no chain of equivalence can be established without a constitutive outside. Mouffe has emphasized throughout her work that political identities are always relational: a 'we' cannot emerge without a 'them'. ${ }^{12}$ The Indignados, in the opening lines of their manifesto, also try to establish a 'we' in opposition to a 'they'. The adversaries are 'bankers, politicians and businessmen' that leave us 'helpless and without a voice'. Within the Occupy movement, a similar attempt to create an adversary can be noticed. By choosing 'we are the $99 \%$ ' as a central slogan, the movement considered the wealthy ' $1 \%$ ' as their adversary. Yet, in both cases, the adversary remains vague, resulting in a kindred vague development of the antagonism itself. For this reason, the Occupy movement and the Indignados have been fiercely criticised by Mouffe. ${ }^{13}$

In brief, the Indignados and Occupy tended to construct a very broad chain of equivalence vis-à-vis a very vaguely identified enemy. The effect was that the unity of the movements had to be precarious as it was very inclusive. As a result, neither Occupy nor the Indignados have been able to transform themselves into lasting counter-hegemonic forces that express a collective will in the form of an alternative political project. Instead, they became volatile movements that only established, at the end of the day, a very weak chain of equivalence. 
However, this does not mean that these new movements were unaware that some form of social unity had to be constructed. Both the Occupy movement and the Spanish Indignados attempted to construct a 'we', yet not in a traditional way. They dismissed traditional leftist discourses on alliances, representation, leadership and strategy, but they did not refrain from building a chain of equivalence as such. ${ }^{14}$ They experimented, or so we claim, with new ways to construct a collective identity. Doubtlessly, the assemblies, manifestos, slogans and shared aesthetics that characterized the movements should be considered as deliberate attempts to create such a discursive unity. These experiments, for that matter, can perfectly be understood and explained in terms of the logic of equivalence, hegemony and antagonism. For the latter inevitably determine the field of discursivity in which any movement operates.

\section{Institutional and Symbolic Effectiveness}

In her critical analysis of the recent protest movements, Mouffe draws a distinction between popular mobilisations 'that follow more traditional left patterns' and 'those that diverge from them'. ${ }^{15}$ While the latter type includes the Spanish Indignados and Occupy, Mouffe refers to the Chilean student movement as an example of the former, and she clearly prefers the approach of this latter movement. In contrast to Occupy or the Indignados, the Chilean movement was formally organised, was based on a visible alliance of social and political forces and was therefore grounded in a conscious articulation of a chain of equivalence. It had elected leaders, did not reject party affiliation and had clear demands that it addressed to the state. Its strategy fits within a long tradition of strategic thinking on the left that owes a lot to the work of Gramsci and especially Poulantzas. To a certain extent, Mouffe's work is a theoretically highly innovative reformulation of this tradition.

An implicit assumption of this strategic framework is that power is located in the state or state-like institutions, against which one should build a counter-hegemony. This happens through the interplay of extra-parliamentary struggles by social movements and mobilisations in civil society on the one hand, and struggles by representative agencies such as political parties within state institutions on the other. The state, in this perspective, is not seen as a unitary subject but as a relation: it is constituted by a set of apparatuses that are criss-crossed by oppositions and conflicts. ${ }^{16}$ This concentric model, typical for domestic politics, also seems to be presupposed in most of Mouffe's works concerning the radicalisation of democracy. The examples of contemporary radical politics Mouffe refers to in Agonistics, namely Syriza in Greece and the Front de Gauche in France, also fit within such a domestic framework. In contrast to these examples, she argues, Occupy and the Indignados are bound to remain ineffective if they refuse to work toward and within institutions, via representative agencies such as parties or trade unions. Mouffe is right to point out that the concrete institutional effects of Occupy and similar movements are very limited. The question, however, is: what is effectiveness? We are confronted with a strange paradox. Compared to the Chilean movement, Occupy and the Indignados were indeed institutionally rather ineffective. Yet, again in contrast to the Chilean case, their symbolic effectiveness was huge. All over the world, people identified with the new protest movements, and started to camp in squares and public places. Occupy thus sparked a global wave of actions and initiatives and was capable of symbolically constructing a point of identification for a global audience. The movement was able to stir the passions of a large number of people all over the world, and made it possible for them to imagine they were part of the same global movement. 
This observation reminds us of Laclau and Mouffe's highly original reading of Rosa Luxemburg's text The Mass Strike, the Political Party and the Trade Unions in Hegemony and Socialist Strategy. What interests Rosa Luxemburg is how a specific struggle can become the spark which ignites the desires and passions of groups in other places, and may stimulate them to also start a struggle. In their interpretation of Luxemburg, Laclau and Mouffe illuminate the symbolic dimension of struggle: a struggle can become a symbol and a point of identification in itself. They point out that the meaning of every mobilisation is split: 'aside from its specific literal demands, each mobilization represents the revolutionary process as a whole'. ${ }^{17}$ ' $[\mathrm{I}] \mathrm{n}$ a revolutionary situation', they write, 'it is impossible to fix the literal sense of each isolated struggle, because each struggle overflows its own literality and comes to represent, in the consciousness of the masses, a simple moment of a more global struggle against the system. ${ }^{18}$

Laclau and Mouffe thus analyse struggle as a symbol that is inevitably characterised by 'the overflowing of the signifier by the signified'. ${ }^{19}$ As this 'overflowing', and the resulting 'emptiness' of the signifier is tendential, however, we can differentiate between different types of struggles as symbols, according to the degree to which such a process of 'emptying' has had its way. Occupy, for example, came to stand for much more than a concrete set of demands formulated by a group of activists in Zuccotti park, but became a symbol in itself: it represented the very possibility to contest the current state of affairs, to ask radical questions and to call for changing the world. ${ }^{20}$ Moreover, Occupy activists seem to have been very aware of the symbolic importance of what they were doing. It is from that perspective that a number of their practices should be understood. Their actions can hardly be considered as part of a strategy; they were primarily of a theatrical nature.

Indeed, in our view, protest movements such as the Indignados or Occupy can be understood as theatrical performances that contributed to a growing de-identification with the present order. The acts through which such processes of de-identification took place - assemblies, occupations, sit-ins - had a lot of similarities with artistic interventions in public space. It is at this point that a link can be made with Mouffe's interpretation of Alfredo Jaar's artistic counter-hegemonic practices. She claims that

[...] Jaar aims at moving people to act by creating in them a desire for change. Discarding the authoritative mode of address, he prefers to interpellate people by setting in motion a process that will make them question their unexamined beliefs. He is convinced that the best way to move people to act is by awakening consciousness of what is missing in their lives and by bringing them to feel that things could be different. ${ }^{21}$

Should the occupation of squares and the organisation of public assemblies not be interpreted along similar lines? Participants in the recent protest movements did not aim to tell people what to do or how to act, rather they wanted to create a consciousness and to show how things could be different. In this sense, the assemblies were, apart from being a form of selfrepresentation also a performance that showed people that a different type of society might be possible. It follows that Occupy and the Indignados have maybe much more in common with types of artistic activism such as Reclaim the Streets or the Yes Men than with traditional political movements; since what they aimed for was symbolic effectiveness through aesthetic and affective means. Think in that regard of the Guy Fawkes masks, the emphasis on slogans and the evocative and affective nature of the opening lines of the manifesto of the Spanish Indignados. In the case of Occupy and the Indignados, this symbolic dimension was also 
translated into a taking of a distance, theorised as 'exodus'. In our view, more than a strategy, exodus must be understood as a part of a performance. The idea of an outside to the existing order was performed, rather than actually pursued. Of course, we do not suggest that protesters should be regarded as artists but rather that the nature of their actions can better be understood from the perspective of artistic practices instead of politico-strategic practices. This insight is rooted in the observation that creative performances or innovative symbols are more and more often mobilised by global movements in order to disrupt post-political representations of the present.

From that perspective, it might also be elucidating to refer to Jacques Rancière's conception of political action to make sense of Occupy and the Indignados. Political action, for Rancière, is theatrical par excellence: it entails the de-identification with the roles and identities of the existing 'police order' and the production of a new political subject by acting on the assumption of equality, thus making visible something that remained previously invisible. Political action disturbs or subverts the existing 'order of the sensible', the order of what is sayable, hearable or visible, and makes it possible for a new political subject to appear, which is both a part and the whole at the same time. It is a part as it is a concrete group of people, while it is a whole to the extent that it renders visible what underlies all social relations, namely equality. ${ }^{22}$

The core feature of a political act, for Rancière, is disidentification and acting as if one is equal. ${ }^{23}$ This is precisely what Occupy and similar movements did. The movements enacted a distancing from and a de-identification with the powers that be. Moreover, its dismissal of representation (or better still: of the institutional division between professional politicians and citizens) was first and foremost an affirmation of equality, giving everyone the right to speak and participate. These movements did not understand themselves as movements originating from a specific social group or class fighting for its rights or interests, but aimed to render visible the capacity of each and everyone to establish 'real' democracy and act in a way that differs from how a presumably corrupt political and economic order functions (as in 'Occupy everything'). In this sense, it made the 'demos' visible, which Rancière understands as the very subject of equality. ${ }^{24}$

At the same time, however, the limits of Rancière's political philosophy are also the limits of movements like the Indignados or other types of artistic activism. For Rancière, the political act is limited to the event through which something new becomes visible. ${ }^{25}$ In a similar vein, artistic activism might trigger something new in the sense of new needs, identifications or insights, but these are not enough to create a new counter-hegemonic order. Mouffe claims:

Contrary to what some artivists seem to believe, however, this does not mean that artivist practices can alone realize the transformations needed for the establishment of a new hegemony. [...] It is an illusion to believe that artistic activism could, on its own, bring about the end of neo-liberal hegemony. ${ }^{26}$

Mouffe's questioning of the strategic effectiveness remains valid. Artistic practices or the reduction of the political to a theatrical gesture are indeed insufficient to create counterhegemony. Although Mouffe tends to underestimate the symbolic effectiveness and artistic dimension of the new movements, she rightly emphasizes the lack of concrete institutional effectiveness. However, in order to acquire a better understanding of the new movements, we cannot avoid the question of why these movements adopted this particular form of protesting. 
Is a mere lack of strategic and political perspicacity a sufficient explanation, or is something more at stake?

Occupy as a Symptom

Mouffe's critical questions about the strategic ineffectiveness of Occupy and like-minded movements are on the mark. Yet, perhaps the picture is more complex than the choice between a post-foundational political ontology and a counter-hegemonic strategy outside and within existing institutions on the one hand, and an operaist ontology combined with an 'exodus' strategy on the other. In this section, we shed a different light on the background of the new protest movements, in order to acquire a better understanding of the importance of their symbolic and theatrical dimension. This focus does not disprove the agonistic approach, but attempts to contribute to a better understanding of the complex predicament in which new social movements find themselves today. Indeed, what if the difficulty of defining an adversary is not merely the result of a poor political ontology or a lack of strategic insight, but the symptom of a political constellation that has become increasingly complex? What if the very conditions for traditional leftist counter-hegemonic strategic thinking have disappeared, or, at least, are perceived as basically lacking? Should we not consider Occupy and similar protest movements as symptoms of a constellation that has dramatically changed over the past decades: a constellation in which the delineation of a clear divide between hegemonic 'antagonists' has become less evident? This predicament may of course be the result of neoliberalism's hegemony and its concomitant post-political representations of society, but there is also the intrinsic complexity of the issues which present-day social movements are dealing with and which makes it all the more difficult to establish a clear-cut and apparent we/them divide.

Mouffe claims that 'an adversary cannot be defined in broad general terms like "Empire", or for that matter "Capitalism", but in terms of nodal points of power that need to be targeted and transformed in order to create the conditions for a new hegemony'. ${ }^{27}$ Likewise, the enemy confronted by recent protest movements cannot be defined in terms of 'the 1\%' or 'the system'. That is correct, but at the same time it begs the question for contemporary radical politics as to how exactly one has to identify the 'nodal points of power' that need to be targeted, and how to construct alternative nodal points? The anonymity (and mobility) of the opponent makes it extremely difficult to locate the latter. Even if one rejects the idea of Empire, it is difficult to deny that it has become increasingly problematic to clearly locate the actual power agencies, let alone to identify a proper adversary. Who is 'Wall Street', for example? Should we target the banks, the bankers, politicians, a street, the entire financial system?

As a result, it seems to have become difficult to delineate what protest movements oppose as such. If everything is financialised (including one's education via student loans, nature through natural capital accounting, social security via pension funds, democracy via public debt etcetera), exactly defining what has to change becomes hard. There is a similar problem with the climate movement. Large parts of this movement also stress the importance of exodus, prefiguration and the construction of the common here and now, which makes them similar to the Occupy movement. Even though it is perfectly possible to point at a handful of big polluters that cause the major part of $\mathrm{CO}_{2}$ emissions, almost everything we do emits $\mathrm{CO}_{2}$ 
and can in principle become the target of environmental action. We can fight climate change by using fewer fossil fuels, by killing wild camels (which is actually done in Australia), or by changing our dietary habits. As all things have an environmental impact, the object of environmental concern can, in principle, be everything. ${ }^{28}$

Of course, there is no pre-given or essential target of political action: the latter is always a hegemonic construction. However, the issues that were targeted by previous protest movements belonged to a social space that was structured in a way that made it easier to determine the object of political action, or, to formulate demands. If confronted with the exploitation of labour, the oppression of women, or racism, it is much easier to identify the main actors, sites and mechanisms responsible for it. These struggles were related to subject positions, which were doubtlessly hegemonically constructed, but they already exhibited a definite structural inscription within the prevailing hegemony.

Furthermore, many Occupy or climate activists stress that we are also included in what we oppose. We create environmental impact by the way we live. We depend on money and banks in our daily lives and we expect interest on our bank deposits. People are always already included in hegemonic configurations, even if they protest against them. ${ }^{29}$ Yet, being part of the capitalist system due to the fact that one earns a wage constitutes a different form of 'inclusion' than participating in the money and financial systems or in a polluting production and consumption system. In the case of the wage relation, there is a clear 'other' that can be constructed into an adversary, namely the employer. In the case of our involvement in more anonymous systems such as finance and pollution, this is different. At least, this is how many activists appear to experience their predicament. From this perspective, it is no coincidence that experimenting with alternative practices here and now (including so-called 'prefigurative practices') has become such an important dimension of many recent protest movements. This complexity does not mean that it has become entirely impossible to point to nodes of power that one can oppose. Yet, it becomes increasingly difficult to establish a clear divide, and to make a strong and convincing case for delineating a 'we' and a 'them'. ${ }^{30}$

In other words, the very issues which spark opposition today and the post-political context within which this opposition is to be enacted, makes it intrinsically difficult to politicise things. The 'artivism' and reflections of many contemporary activists should be understood against this backdrop. If financialisation is reaching into the very details of our lives and if everything we do has an environmental impact, 'everything' should be changed, including ourselves. 'Occupy everything' is a significant slogan in this regard: it testifies to the idea that it has become less easy to exactly identify or locate the nodes of power. The slogan reveals the difficulty of pointing at concrete nodes which should strategically be prioritized. Significantly, the Occupy and the Indignados have a very limited notion of the enemy (the ' $1 \%$ ', the bankers, politicians), and at the same time a very broad one (including all political parties, representative institutions and agencies, which have been 'sold' to the financial system).

Gramsci argues that one does not choose the terrain of struggle oneself, but that it is to a large extent determined by the adversary. ${ }^{31}$ What Occupy and similar movements do, is trying to reverse this order, largely under pressure of the specific conditions of their struggle: not to chase the adversary on the latter's place (which it is difficult to locate), but to occupy a proper place. If the terrain of struggle cannot be clearly located and determined, social movements will have to create it by themselves. It is in relation to this observation, that one should understand the symbolic and artistic character of radical protest movements today. The 
theatrical gestures are attempts to create a space in which the struggle becomes representable. It entails an unsettling of common sense and the theatrical pre-figuration of an alternative order. More than reading these movements as organized along the lines of already established we/them distinctions, they must be seen as attempts to recreate the conditions of possibility for such (ant)agonistic distinction.

Take, for example, the notion of exodus. As Mouffe rightly stresses, 'exodus' is far from an effective strategy to realise change. ${ }^{32}$ Yet, as mentioned earlier, perhaps it should not be conceived as a strategy, but rather as a primordial symbolic and theatrical act that serves as a precondition for establishing a 'we'. Indeed, pointing to the system as a whole as the opponent triggers the question who 'we' are and where we stand. What the slogan of 'exodus' calls for, therefore, is the very enactment of a 'constitutive outside' that is the necessary condition for clearly delineating a 'them'. Taking into account the specificity of the encompassing problems contemporary protest movements are confronted with, exodus and other symbolic acts which provoke de-identification appear to be a precondition for establishing a 'we' and a 'them', and thus for creating an agonistic space.

\section{Conclusion}

This article is an attempt to use Mouffe's agonistic approach to shed an alternative light on Occupy and similar movements, and to reformulate Mouffe's critique of these movements. Part of the effort was oriented to showing that the agonistic framework provides the tools for a more adequate description of the movement than (post-autonomist and other) theories however influential they may be within these movements themselves. Indeed, nothing prevents us from considering the new protest movements as attempts to create a chain of equivalence between widely differing and isolated demands. Under these conditions, central signifiers such as 'Occupy', 'Real Democracy Now!' or 'the 99\%' have become empty signifiers that represent and produce the fragile unity of these movements as such.

The recent protest movements focused on the creation of a chain of equivalence that would be as wide as possible, without however clearly defining an adversary or giving the formulation of concrete demands the place it should have. Focusing in particular on the symbolic and performative constitution of a 'we', they were symbolically effective, but at the same time institutionally weak and rather volatile. In our view, this specific mode of organizing and staging the protests cannot be simply reduced to a strategic or ideological choice made by the participants or certain key figures within those movements. The type of protests we witnessed during bygone years should also be understood as addressing the present constellation in which it becomes increasingly difficult to determine who is the adversary and where s/he is located.

More specifically, the difficulty of locating and identifying the adversary has to be understood against the background of two processes that are partly interrelated. First and foremost, there is the process of depoliticisation that has made it increasingly difficult to visibly construct clear we/them distinctions. Secondly, there is the specific character of the issues targeted by recent protest movements and the way they are structurally embedded in the contemporary mode of functioning of capitalism. In case of financial capitalism, for example, it is far from self-evident to locate the place of power or to identify the actors who make crucial decisions. 
Mouffe's call for a truly counter-hegemonic political project that defines its adversaries in political terms is justified. Yet, the conditions under which such strategy is possible are changing. The nation state and its institutions are no longer the privileged place where the current order can be challenged. The contemporary political and economic order is constructed in such way that a clear delineation between different hegemonic groups is far from evident. It is our hypothesis that movements such as Occupy or the Indignados should be understood as attempts to re-politicise the current constellation. From a theoretical point of view, their symbolic strategies deserve a thorough investigation, which should fertilise the hard-needed reflection on how to develop new and effective strategies for building agonistic political spaces. Many activists in the recent movements intuitively felt that the complexity of the new global order calls for a different type of radical politics. This is at least one of the reasons why a large part of the protestors were hostile towards parliamentary democracy and existing political parties. In contrast to post-operaist interpretations, this should not be understood in terms of an exodus strategy but rather as a symbolic attempt to repoliticise the given constellation. It is related to a theatrical performance through which a distance is enacted from the (increasingly anonymous) powers behind recent crises. More than a deliberate strategy, this de-identification should be understood as a symbolic act. In this regard, the assemblies organized by the Indignados and Occupy were more than decision making procedures: they were symbolic performances in which participants treated each other as if everybody was equal. Enacting (the very possibility of) an alternative order is a political act par excellence through which the adversary is not defined but rather provoked to identify himself $a s$ the adversary. In our view this is the fundamental significance of movements like Occupy and the Indignados: within a complex and depoliticised order they attempt to create the conditions wherein new types of agonistic struggle may occur.

To conclude, we can state that Occupy and comparable movements symbolically manifested themselves 'outside' the hegemonic order - which, of course, is eventually impossible. Yet, they thus established the symbolic preconditions for an intense and broad process of identification for people all over the world. In this sense, movements like Occupy (such as the mostly theatrical and symbolic nature of the alterglobalisation or radical climate movement) constitute a first step in a process of (re)politicisation. Occupy, in this sense, contributed to making society 'readable' or interpretable again in terms of we/them distinctions. However, as Mouffe has stressed, the unsolved riddle remains how to translate this symbolic effectiveness into institutional effectiveness.

\section{Notes}

${ }^{1}$ David Graeber, The Democracy Project. A History. A Crisis. A Movement (London: Penguin, 2013), p.154. See also Antonio Negri and Michael Hardt, Déclaration. Ceci n'est pas un manifeste (Paris: Raisons d'Agir, 2013).

${ }^{2}$ Chantal Mouffe, Agonistics. Thinking the World Politically (London and New York: Verso, 2013), p.78.

${ }^{3}$ Chantal Mouffe, Agonistics. Thinking the World Politically, p.108.

${ }^{4}$ Ernesto Laclau and Chantal Mouffe, Hegemony and Socialist Strategy. Towards a Radical

Democratic Politics (London and New York: Verso, 2001), p.136.

${ }^{5}$ Ernesto Laclau, New Reflections on the Revolution of Our Time (London and New York: Verso, 1990), p.61. 
${ }^{6}$ Ernesto Laclau, 'Deconstruction, Pragmatism, Hegemony' in Deconstruction and

Pragmatism, ed. Chantal Mouffe (London and New York: Routledge, 1996), p.62.

${ }^{7}$ David Howarth and Yannis Stavrakakis, 'Introducing Discourse Theory and Political Analysis', in Discourse Theory and Political Analysis, ed. David Howarth, Aletta J. Norval and Yannis Stavrakakis (Manchester: Manchester University Press, 2000), p.15.

${ }^{8}$ This view on representation is inspired by Marcel Gauchet, La réligion dans la démocratie.

Parcours de la laïcité (Paris: Éditions Gallimard, 1998), p.156.

9 'Manifesto', http://www.democraciarealya.es/manifiesto-comun/manifesto-english/ (2011).

(access date: 28/11/2013.

${ }^{10}$ Ernesto Laclau, On Populist Reason (London and New York: Verso, 2005), p.99.

${ }^{11}$ Ernesto Laclau, 'The Death and Insurrection of the Theory of Ideology', MLN, 112 (1997), p. 305.

${ }_{12}$ Chantal Mouffe, The Democratic Paradox (London and New York: Verso, 2005), p.56.

${ }^{13}$ Chantal Mouffe, Agonistics. Thinking the World Politically (London and New York: Verso, 2013), p.117.

${ }^{14}$ This is also suggested by Mouffe. Chantal Mouffe, Agonistics. Thinking the World Politically, p.117.

${ }^{15}$ Chantal Mouffe, Agonistics. Thinking the World Politically, p.109.

${ }^{16}$ Nicos Poulantzas, The Poulantzas Reader: Marxism, Law and the State, ed. James Martin (London: Verso, 2008).

${ }^{17}$ Ernesto Laclau and Chantal Mouffe, Hegemony and Socialist Strategy. Towards a Radical Democratic Politics, p. 11.

${ }^{18}$ Ernesto Laclau and Chantal Mouffe, Hegemony and Socialist Strategy. Towards a Radical Democratic Politics, p.10.

${ }^{19}$ Ernesto Laclau and Chantal Mouffe, Hegemony and Socialist Strategy. Towards a Radical Democratic Politics, p. 11.

20 The slogan for 'World Revolution' underscores this. Literally speaking, this seems a ridiculous and unrealistic demand, but symbolically, it was highly effective.

${ }^{21}$ Chantal Mouffe, Agonistics. Thinking the World Politically, p.95.

${ }^{22}$ Peter Hallward, 'Staging Equality. On Rancière's Theatrocracy', New Left Review, 37 (2006), pp.109-129.

${ }^{23}$ Jacques Rancière, Aux Bords du Politique (Paris: Gallimard, 1998), p.212.

${ }^{24}$ Jacques Rancière, Disagreement: Politics and Philosophy (Minneapolis: University of Minnesota, 1999), p. 8.

${ }^{25}$ For Rancière, from the moment one attempts to build a new social order, one is inevitably caught again in the web of hierarchical relations. This neat circumscription of the political act goes back to the ideas of Rancière's source of inspiration, Joseph Jacotot, who argued the radical equality of intelligences can only be realised in personal interactions, and can never be institutionalised. Jacques Rancière, Aux Bords du Politique (Paris: Gallimard, 1998), p.162.

${ }^{26}$ Chantal Mouffe, Agonistics. Thinking the World Politically, p.99.

${ }^{27}$ Chantal Mouffe, Agonistics. Thinking the World Politically, p.75.

${ }^{28}$ Anneleen Kenis and Matthias Lievens, 'Searching for the Political in Environmental Politics', Environmental Politics [forthcoming].

${ }^{29}$ This follows directly from Mouffe's ontological position. Chantal Mouffe, On the Political (London and New York: Routledge, 2005), p.17.

${ }^{30}$ Especially the way financialised capitalism functions, makes it terribly complex to fight it. It deploys a subtle mechanism by which public policies are systematically punished whenever they run against the interests of the financial markets. Raising taxes, as the French government is currently doing (and which Mélenchon would probably also do), directly leads 
to a decrease of investment and the flight of capital. Redistributive social policies or strict environmental regulations would have similar effects. As a result, politicians consider themselves as predominantly accountable to the financial markets, as it is these markets that decide on the 'health' of a state and its 'governance'.

${ }^{31}$ Antonio Gramsci, Selection from the Prison Notebooks, ed. and trans. Quintin Hoare and Geoffrey Nowell Smith (New York: International Publishers, 2010), p.172.

${ }^{32}$ Chantal Mouffe, Agonistics. Thinking the World Politically, p.125.

Thomas Decreus is a doctoral student for the Centre of Ethics, Social and Political Philosophy at the Institute of Philosophy (University of Leuven). His current research focuses on the relationship between political representation, hegemony and democracy. Recent publications are: 'Beyond representation? A Critique of the concept of the referent', Representation 49:1 (2013) and 'The powerlessness of the Flemish nationalists', Belgian Society and Politics 5 (2011). Email: Thomas.Decreus@hiw.kuleuven.be

Matthias Lievens is a post-doctoral researcher at the Institute of Philosophy and the Leuven Centre for Global Governance Studies (KU Leuven, Belgium). He wrote a dissertation on Carl Schmitt's concept of the political, and is currently leading an interdisciplinary research team working on the democratization of global governance. He has published on post-foundational political philosophy, democratic theory and political ecology in journals such as Constellations, Environmental Politics, Contemporary Political Theory and Philosophy and Social Criticism. Email:

Matthias.Lievens@ggs.kuleuven.be

Antoon Braeckman is professor of contemporary social and political philosophy at KU Leuven, where he co-directs the RIPPLE research group in political philosophy (http://www3.kuleuven.be/ripple/index.html). His research focuses on issues like modernity, community building, political representation and democracy. Email: Toon.Braeckman@kuleuvenkulak.be 